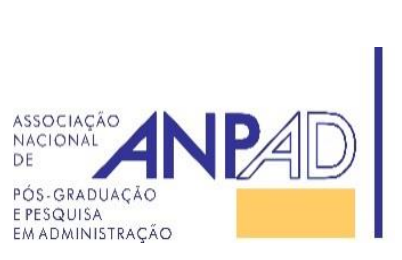

Available online at

http://www.anpad.org.br/bar

BAR, Rio de Janeiro, v. 13, n. 4, art. 1,

e150067, Oct./Dec. 2016

http://dx.doi.org/10.1590/1807-7692bar2016150067

(c) BY

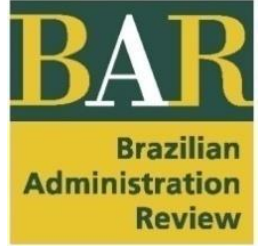

\title{
Redefining the Relationship between Intellectual Capital and Innovation: The Mediating Role of Absorptive Capacity
}

\author{
Alessandra Cassol ${ }^{1,2}$ \\ Cláudio Reis Gonçalo ${ }^{3}$ \\ Roberto Lima Ruas ${ }^{1}$
}

Universidade Nove de Julho ${ }^{1}$

Universidade do Contestado ${ }^{2}$

Universidade do Vale do Itajai ${ }^{3}$

Received 12 November 2015; received in revised form in 6 October 2016 (this paper has been with the authors for two revisions); accepted in 24 October 2016; published online 18 November 2016. Editor's note. Jorge Carneiro served as Associate Editor for this article. 


\begin{abstract}
The objective of this study is to analyze the relationship between absorptive capacity, intellectual capital and innovation. The main purpose of this research is to demonstrate that absorptive capacity can leverage the relation between intellectual capital and innovation potential. The method was a single case study using exploratory and descriptive research strategies and applying both quantitative and qualitative techniques. The case study investigated was a Brazilian corporation that has been doing business in the paper and corrugated cardboard industry for 72 years. The paper describes a case analysis demonstrating that adoption of practices associated with absorptive capacity has potential to foster intellectual capital, which is particularly important for development of innovations. These practices include assimilation of new technologies; creating capacity to utilize existing internal knowledge held by employees; use of benchmarking; application of technical knowledge; and registration of patents. Triangulation of data provided evidence confirming that the relationship between absorptive capacity and intellectual capital is a driver of innovation in the firm investigated. Additionally, this relationship is better explained by the mediating role of absorptive capacity, which is capable of potentiating intellectual capital to foster innovation.
\end{abstract}

Key words: intellectual capital; absorptive capacity; innovation. 


\section{Introduction}

Environmental dynamism places ever-growing demands on firms to find new organizational structures. These structures must be capable of simultaneously generating several different sources of internal and external information to support decision-making processes. In this theoretical context, management of intellectual capital defined as a valuable internal resource can contribute to driving innovation capacity.

It is not a new discovery that management of intellectual capital can potentiate innovation, but it still remains necessary to elucidate how the relationship between the two can be promoted in such a way as to adapt to this dynamic scenario. The underlying assumption of this qualitative research is that absorptive capacity (AC) can potentiate this relationship between intellectual capital and innovation, enabling firms to achieve better utilization and integration from individual knowledge to collective knowledge. As such, the objective of this study is to analyze how intellectual capital can be developed through $\mathrm{AC}$ and potentiate innovation as a result.

Over recent years, several well-received studies have highlighted the need to understand utilization of intellectual capital as a factor that can mobilize organizations' innovation potential (Dumay \& Garanina, 2013; Edvinsson, 2013; Guthrie, Ricceri, \& Dumay, 2012; Santos, Basso, \& Kimura, 2012; Stoeckicht \& Soares, 2012). This paper attempts to contribute to this effort by focusing specifically on the relationship between intellectual capital and innovation potential, through the concept of $\mathrm{AC}$. We are therefore working from the assumption that $\mathrm{CA}$ can expand the potential for generation of innovation, as theorized by Lane, Koka and Pathak (2006), who argue that CA can increase the velocity, frequency and magnitude of innovation in firms.

We then suggest that when a firm develops and manages CA, this process can contribute to development of new capabilities, such as innovation, thereby conferring factors of competitive differentiation that place them at the forefront of problem solving. The underlying research question that this study aims to answer is: How can CA leverage intellectual capital to increase innovation potential?

This article describes a single case study that was investigated using exploratory and descriptive research strategies and employing quantitative and qualitative techniques. It is recognized, therefore, that there is no possibility of statistical generalization. Theoretical hypothesis is analyzed from the specific empirical context. The next section describes the theoretical framework within the relationship between intellectual capital and AC and innovation is conceptualization. The third section describes the study methodology and then section four presents and discusses the results found, section five closes the article with some final comments.

\section{Literature Review}

\section{Intellectual capital as a strategic resource for organizations}

Intellectual capital is studied from the perspective of the knowledge-based view, which is itself built on the foundations of the resource-based view, on the theory of organizational learning and on organizational theory (Acedo, Barroso, \& Galan, 2006; Eisenhardt \& Santos, 2002). More specifically, one line of research into management of knowledge in organizations focuses on intellectual capital. This research avenue's principal argument is related to seminal work conducted by Sveiby (1997) and by Edvinsson and Malone (1998), who investigated the phenomenon of intangible assets.

The elements making up intellectual capital can be categorized into different dimensions, such as Human Capital, Structural Capital and Relational Capital. Human Capital is referred to knowledge that 
is intrinsic to people and which is related to their capacities, skills and abilities, experience, creativity and innovation. Structural Capital evolves the tools used to transform individuals' knowledge into organizational assets. Relational Capital is characterized by the relationships with stakeholders such as strategic alliances, collaborative relationships, joint ventures, industry associations or partnerships (Edvinsson \& Malone, 1998; Ienciu \& Matis, 2011; Lima \& Antunes, 2011; Sveiby, 1997).

In organizations there is a relationship between intellectual capital and capacity to innovate. These intangible assets have a significant influence on innovation and maintenance of superior and sustained business performance (Luca, Maia, Cardoso, Vasconcelos, \& Cunha, 2014).

It is known, for example, that organizations adopt different approaches of accumulation and use of their knowledge and that these practices are manifested in different aspects of intellectual capital (human, organizational and relational capital) (Davenport \& Prusak, 1998; Nahapiet \& Ghoshal, 1998; Schultz, 1961). However, there is still a need to investigate practices that demonstrate the capacity to establish the relationship between intellectual capital and generation of innovation.

Demartini and Paoloni (2013), in a survey conducted in a large company which was a leader in defense systems located in Italy, found out that the company's CEO demonstrated his interest in increasing the intellectual capital of the company through implementation of an organizational unit fully dedicated to promote product innovation, increasing the number of patents and trademarks, strengthening personal skills and institutional relationships.

Zhang, Qi, Wang, Pawar and Zhao (2015), from a survey conducted in Chinese and Indian industries, found out that direct impact of knowledge integration on innovation performance is significant only in India, and the effect of intellectual capital in innovation performance is significantly higher in China than in India. While Costa, Fernández and Dorrego (2014) argue that the elements of human capital and relational capital affect product innovation indirectly through its interaction with the structural capital.

This study is therefore intended to contribute to the literature through a demonstration of how organizations can utilize the intellectual capital intrinsic to their environments and illustrating the ways in which they can direct it to generate innovations. Therefore, the first research hypothesis (H1) investigated in this study will be as follows:

Hypothesis 1: the greater an organization's intellectual capital is, the greater will be its capacity to generate innovation.

\section{Absorptive capacity (AC): a challenge in organizational management}

The term AC was first introduced and defined by W. M. Cohen and Levinthal (1989) to describe a firm's capacity to identify, assimilate and exploit information available in its environment. Zahra and George (2002, p. 186) define AC as "a set of organizational routines and processes by which firms acquire, assimilate, transform and exploit knowledge to produce a dynamic organizational capacity".

Intellectual capital is recognized as a key factor to drive assimilation of external knowledge (Hagemeister \& Rodríguez-Castellanos, 2010). Furthermore, the capacity of this assimilation depends on prior knowledge of the company (Lane, Koka, \& Pathak, 2006), which is understood as more relevant than the sum of knowledge of individuals (W. M. Cohen \& Levinthal, 1990).

Mariano and Walter (2015) suggest that empirical researches on the absorptive capacity in the fields of knowledge management and intellectual capital should be directed to explore and explain contributions of intellectual capital factors to organizational dynamic processes. The study by T.-C. Lin, Chang and Tsai (2016) explored the relationship between the loss of knowledge and decrease of absorptive capacity, providing empirical evidence on impacts of the loss of knowledge including in performance decrease. 
Then, we propose that the intellectual capital has a positive influence on the absorptive capacity of the company (AC), being the basis of the second hypothesis to be tested (H2):

Hypothesis 2: the greater the organization's intellectual capital is, the greater will be its AC.

For the purposes of interpretation, $\mathrm{AC}$ can be subdivided into two dimensions: potential $\mathrm{AC}$ and realized AC. Potential AC can be considered as a baggage of knowledge that has been acquired and assimilated, but which remains in a dormant state until a real use for the knowledge emerges; in turn, realized $\mathrm{AC}$ is concerned with transformation and application of previously acquired knowledge to achieve a competitive advantage to be developed over the short or medium term (Zahra \& George, 2002).

Cooperation in innovation is related to the potential absorptive capacity, as it refers to activities directed to innovations developed with different types of partners, such as suppliers, customers, competitors, consultants and universities. These can provide increase of the company's capability to transfer relevant information and tacit knowledge (Murovec \& Prodan, 2009).

Innovation success also depends on the extent to which external technology opportunities to the company can be used for own purposes (W. M. Cohen, 2010). Especially in environments with high pressure of competitors, companies need to open their innovation process and include external knowledge to enhance their innovation generation capacity.

The absorptive capacity of external knowledge can be a source of performance so that the company improves innovation (Wang \& Han, 2011). Some studies, such as Chen, Lin and Chang (2009), Wang and Han (2011), C. Lin, Wu, Chang, Wang and Lee (2012) conclude that absorptive capacity has a strong positive relationship with innovation.

Companies with a well-developed absorptive capacity and well-implemented learning mechanisms will be more prone to generation of innovation. Absorptive capacity has a positive effect on innovation capacity, i.e., acquisition and assimilation of knowledge and ability to turn it into a newly created knowledge allows creating new ideas and innovation in the context of project teams (LealRodríguez, Roldán, Ariza-Montes, \& Leal-Millán, 2014). Companies should not only manage external accumulation of knowledge, but also adapt their skills (systematizing, coordinating and promoting dissemination of knowledge) in order to succeed with the generation of innovation (Vicente-Oliva, Martínez-Sánchez, \& Berges-Muro, 2015).

A firm's capacity to assimilate and exploit knowledge may be related to utilization of this knowledge in the search for forms of innovation. The third hypothesis (H3) of this study is based on the premise that $\mathrm{AC}$ is able to potentiate a range of different forms of innovation generation at different levels and different types.

Hypothesis 3: the greater an organization's AC is, the greater will be its capacity to generate innovation.

\section{Innovation as a competitive advantage}

Innovation has been subject of many concepts (Freeman \& Soete, 2008; Rogers, 1962; Tidd, Bessant, \& Pavitt, 2008; Utterback, 1971), although the majority of these authors present conceptualizations of innovation that emphasize very similar elements to those originally proposed by Schumpeter (1934/1997). For the purposes of this study, the concept will be adopted as defined by Tidd, Bessant and Pavitt (1998), who state that innovation is the process of transforming opportunities into new ideas and putting them into practice. It is understood that the innovation process is dependent on AC. These authors (Tidd et al., 2008) draw on concepts from work by Schumpeter (1934/1997) to arrive at a model of four different types of innovation: (a) Product innovation: introduction of a new good or service, or improvement of its characteristics or intended use; (b) Process innovation: methods of production or supply of new or significantly improved ones, in order to reduce unit costs or increase 
product quality; (c) Position innovation: implementation of new methods in the marketing or trading area; (d) Paradigm innovation: new organizational methods in business practices, in the organization of the workplace or external relations of the company.

Implementing a strategy based on the concept of AC can mobilize an organization to create new projects more quickly, with more appropriate allocation of personnel to teams and, the most important, minimizing knowledge gaps between teams and organizations, which will potentiate knowledge that already exists, focusing it on development of innovations (C. Lin, Wu, Chang, Wang, \& Lee, 2012). It has also been observed that employing a variety of different internal resources can influence the dimensions of AC, and then produce different results in terms of innovation and performance (Machado \& Fracasso, 2012).

The company may be able to acquire external knowledge, but it can be difficult to assimilate and apply this knowledge. It is proposed that the absorptive capacity can significantly increase the performance of business innovation (Tseng, Chang Pai, \& Hung, 2011) since the company has a level of prior knowledge (intellectual capital) able to assimilate external knowledge which was acquired.

Companies are required to acquire external knowledge and to develop absorptive capacity for developing the magnitude of innovation and organizational performance. Many companies acquire external knowledge through different means, including mergers and acquisitions (M \& A) and strategic alliances, mainly in the sectors of intensive R \& D in which technological innovation is emphasized (Jeon, Hong, Ohm, \& Yang, 2015).

Duchek (2013) suggests that further analysis of practices for absorbing knowledge can make important contributions to open the black box of the absorptive capacity and indicate how to empirically capture this complex construct. Tortoriello (2015) also shows that other contingencies in the relationship between external knowledge and the generation of innovation could provide important insights on how organizations benefit from the absorptive capacity of their employees.

It is therefore understood that firms that are able to utilize their intellectual capital strategically, developing it through application of their $\mathrm{AC}$, are more likely to innovate and, consequently, become or remain innovative companies. The fourth hypothesis $(\mathrm{H} 4)$ predicts that $\mathrm{AC}$ mediates the relationship between intellectual capital and innovation.

Hypothesis 4: AC mediates the relationship between intellectual capital and innovation.

The fourth hypothesis is founded on the statement that organizational knowledge must be shared and potentiated in a dynamic internal process so that, among other results, it can drive creation of organizational innovations (Flatten, Engelen, Zahra, \& Brettel, 2011). This process can be achieved through practices related to AC. It is therefore assumed that, the mediating role played by AC can potentiate utilization of intellectual capital for development of innovations in firms.

\section{Methodological Procedures}

The method was a single case study using exploratory and descriptive research strategies and applying both quantitative and qualitative techniques. The case in question is a Brazilian corporation that has been doing business in the paper and corrugated cardboard industry for 72 years. On the domestic level, the company has factories in four Brazilian states: Rio Grande do Sul, Santa Catarina, São Paulo and Minas Gerais. On the international stage, the company does business in the United States, a number of European countries, Argentina, Chile and Saudi Arabia.

This company was chosen as the object of research because it meets the prerequisites for an innovative company, as defined by Tidd et al. (1998). It has a dedicated research and development department that was set up in 2006 and also a corporate innovation department, with research staffs who 
hold Masters and Doctoral degrees and have been working to develop innovations since 2010. It has taken actions such as creating a corporate innovation department; innovation-oriented strategic planning and training; and innovation-stimulation programs. From the temporal perspective, this is a crosssectional study (Malhotra, 2012).

Preparatory to the quantitative data collection phase, adapted versions were prepared of items from questionnaires originally developed by Gracioli, Godoy, Lorenzett and Godoy (2012), by Camisón and Forés (2010) and by Stoeckicht and Soares (2012) for measurement of intellectual capital, AC, and innovation, respectively. The adaptation process was designed to make the items applicable and comprehensible in the setting of the organization under investigation. The resulting instrument was then subjected to a pre-test of face validity with six members of the company's management. After validation, the questionnaire was sent by e-mail to the sample population. The final questionnaire comprises 24 closed questions with responses distributed along a five-point Likert scale (ranging from agree to disagree). The questionnaire was only administered to managers, coordinators and supervisors, breaking down as follows: 27 managers, 78 coordinators and 44 supervisors, making a total sample population of 149 respondents, distributed across all of the company's factories. There were 104 respondents out of the total population of 149 managers, which equates to $70 \%$ participation in the quantitative phase.

The instrument was validated with confirmatory factor analysis by Partial Least Squares (PLS), using Smart PLS software. Data were analyzed using the structural equation modeling (SEM) statistical analysis method, also by Partial Least Squares (PLS). Structural equation modeling enables analysis of the relationships between multiple variables simultaneously, whether latent or observed (Hair, Black, Babin, Anderson, \& Tatham, 2009; Malhotra, 2012). Analysis of descriptive statistics and calculation of frequencies and percentages of non-numerical data was performed using SPSS ${ }^{\circ}$ version 21.0.

The PLS method is recommended by Hair, Ringle and Sarstedt (2011), who state that the technique provides estimates and parameters that maximize the variance explained ( $\mathrm{R}^{2}$ values) by the models under investigation. Another reason for choosing the PLS method is its flexibility with regard to assumptions about the distribution of data, such as normality, the use of interval scales and large samples (Hair, Hult, Ringle, \& Sarstedt, 2013). The existence of a mediating effect of AC on the relationship between the independent variable intellectual capital and the dependent variable innovation was investigated using the SOBEL test (Sobel Test Calculator for the Significance of Mediation). According to Baron and Kenny (1986), in management studies investigating single mediation effects, the Sobel test is used to compare the strength of indirect effect that an independent variable exerts on the dependent variable, in which the null hypothesis is that this effect is equal to zero. In order to increase the reliability of this test we also applied the Variance Accounted For or Variance Explained test proposed by Hair, Hult, Ringle and Sarstedt (2013).

In order to measure intellectual capital, the questionnaire proposed by Gracioli et al. (2012) was adapted, as shown in Table 1. 
Table 1

Variables and Measures for Intellectual Capital

\begin{tabular}{|c|c|}
\hline Variables & Measures \\
\hline Human Capital & $\begin{array}{l}\text { HC1 Employees participate in company decisions. } \\
\text { HC2 Employees are always creative and take initiative. } \\
\text { HC3 The majority of employees have worked for the company for many years. } \\
\text { HC4 The employees have a high level of education/qualification. } \\
\text { HC5 The company makes long-term investment in its employees. } \\
\text { HC6 The employees are committed to the company. } \\
\text { HC7 The employees are well trained. } \\
\text { HC8 Expenditure on training is high. } \\
\text { HC9 There is trust between the company and its employees. } \\
\text { HC10 Experimentation is encouraged. } \\
\text { HC11 Employees have the competencies needed to innovate in their roles. } \\
\text { HC12 Employees are creative and innovative. } \\
\text { HC13 If a key employee leaves the company there will be losses. } \\
\text { HC14 There is high employee turnover. }\end{array}$ \\
\hline Structural Capital & $\begin{array}{l}\text { SC1 There is increasing investment in new methods and systems. } \\
\text { SC2 The company has been in the market for a long time. } \\
\text { SC3 Employees' suggestions are implemented. } \\
\text { SC4 There is improvement of the technical capacity of production processes. } \\
\text { SC5 Products are delivered to customers quickly and efficiently. } \\
\text { SC6 Losses and wastage have been reduced. } \\
\text { SC7 Customers' complaints have reduced. } \\
\text { SC8 The rate of defects has been reduced. } \\
\text { SC9 The number of R\&D employees has increased. } \\
\text { SC10 Creative ideas are passed on to everybody. } \\
\text { SC11 The time spent on research and development has increased. } \\
\text { SC12 Information systems pass on information to everyone in the company. } \\
\text { SC13 The company philosophy is to incentivize and encourage participation. } \\
\text { SC14 Information obtained from customers is always communicated to everyone. }\end{array}$ \\
\hline Relational Capital & $\begin{array}{l}\text { CC1 The proportion of orders has increased. } \\
\text { CC2 The number of new customers and new orders have increased. } \\
\text { CC3 Customers are completely satisfied with the company. } \\
\text { CC4 Sales have increased significantly. } \\
\text { CC5 Customers are satisfied with price, quality and delivery times. } \\
\text { CC6 The company's brand is well-known in the market. } \\
\text { CC7 The company has an excellent reputation with customers and suppliers. } \\
\text { CC8 Partnerships with suppliers and customers are strong. } \\
\text { CC9 The company identifies customers' requirements. }\end{array}$ \\
\hline
\end{tabular}

Note. Key to Variables: HC - Human Capital; SC - Structural Capital; CC - Relational Capital.

In order to measure absorptive capacity, we adapted the questionnaire proposed by Camisón and Forés (2010), who proposed to study the routines, mechanisms and activities that make up the CA (Table 2). 
Table 2

Variables and Measures to Absorptive Capacity

\begin{tabular}{|c|c|}
\hline Variables & Measures \\
\hline \multirow[t]{3}{*}{$\begin{array}{l}\text { Acquisition } \\
\text { Capacity }\end{array}$} & $\begin{array}{l}\text { ACC1 - The company has the capacity to capture relevant, continuous, up-to-date information } \\
\text { and knowledge on current and potential competitors. }\end{array}$ \\
\hline & $\begin{array}{l}\text { ACC2 - The company management is oriented towards waiting to see what happens, instead } \\
\text { of concern for and orientation towards their environment to monitor trends in a continuous } \\
\text { and wide-ranging manner and to discover new opportunities to be exploited proactively. }\end{array}$ \\
\hline & $\begin{array}{l}\text { ACC } 3 \text { - The company gives importance to and frequently engages in cooperation with R\&D } \\
\text { organizations, universities, business schools, technological institutes, etc., as a member or } \\
\text { sponsor to create knowledge and innovations. }\end{array}$ \\
\hline \multirow[t]{3}{*}{$\begin{array}{l}\text { Assimilation } \\
\text { Capacity }\end{array}$} & $\begin{array}{l}\text { ASC1 The company has the capacity to assimilate new technologies and innovations that are } \\
\text { useful or have proven potential. }\end{array}$ \\
\hline & $\begin{array}{l}\text { ASC } 2 \text { The company has the ability to use employees' knowledge, experience and competencies } \\
\text { in the assimilation and interpretation of new knowledge. }\end{array}$ \\
\hline & $\begin{array}{l}\text { ASC } 3 \text { The company has the ability to develop knowledge management programs, } \\
\text { guaranteeing the firm's capacity for understanding and carefully analyzing knowledge and } \\
\text { technology from other organizations. }\end{array}$ \\
\hline \multirow[t]{4}{*}{$\begin{array}{l}\text { Transformation } \\
\text { Capacity }\end{array}$} & $\begin{array}{l}\text { TC1 The company has the capacity to use information technology to improve the flow of } \\
\text { information, achieve effective sharing of knowledge and foster communication between } \\
\text { members of the company, including virtual meetings among employees who are physically } \\
\text { distant using: Internet, e-mail, videoconferences, teleconference. }\end{array}$ \\
\hline & $\begin{array}{l}\text { TC2 The company creates barriers that impede all employees from voluntarily passing on useful } \\
\text { scientific and technological information they have acquired to others. }\end{array}$ \\
\hline & $\begin{array}{l}\text { TC3 The company has the capacity to adapt technologies created by others to the company's } \\
\text { specific requirements. }\end{array}$ \\
\hline & $\begin{array}{l}\text { TC4 The company has the capacity to coordinate and integrate all phases of the R\&D process } \\
\text { and their interrelations with the functional tasks of engineering, production and sales. }\end{array}$ \\
\hline \multirow[t]{3}{*}{$\begin{array}{l}\text { Exploitation } \\
\text { Capacity }\end{array}$} & $\begin{array}{l}\text { EC1 The company has the capacity to exploit new knowledge at work and rapidly respond to } \\
\text { changes in its environment. }\end{array}$ \\
\hline & $\begin{array}{l}\text { EC2 The company achieves a high degree of application of the knowledge and experience } \\
\text { acquired in the technological and business fields. }\end{array}$ \\
\hline & $\begin{array}{l}\text { EC } 3 \text { The company has the capacity to turn technological knowledge into patents for products } \\
\text { and processes. }\end{array}$ \\
\hline
\end{tabular}

Note. Key to Variables: ACC - Acquisition Capacity; ASC - Assimilation Capacity; TC - Transformation Capacity; PAC Exploitation Capacity.

In order to understand the innovation practices, we adapted the questionnaire of Stoeckicht and Soares (2012), aiming to analyze how the factors listed below can stimulate or restrict innovation of enterprises: strategies, objectives, goals, organizational culture and values, structural features, people and business infrastructure, management models and management systems (Table 3). 
Table 3

Variables and Measures for Innovation

\begin{tabular}{ll}
\hline Variables & Measures \\
\hline Marketing Innovation & $\begin{array}{l}\text { MI1 The company uses partner firms', financial and technological human resources to } \\
\text { develop its portfolio of innovative projects. } \\
\text { MI2 The company monitors social networks and uses formal and informal social } \\
\text { networks, such as blogs, discussion forums, Twitter, Facebook, Orkut and other media to } \\
\text { monitor and evaluate the impact of launching its innovations. }\end{array}$ \\
\hline Product Innovation & PRDI1 The company develops new products. \\
& PRDI2 The company develops improvements to existing products. \\
& PRDI3 The company has created or improved products using employees, customers or \\
& suppliers' ideas. \\
\hline Process Innovation & PRCI1 The company develops new production methods. \\
& PRCI2 The company is improving its current production methods. \\
& PRCI3 The company seeks to apply new technologies in its production systems. \\
\hline Organizational & OI1 The company develops strategic competencies for innovation aiming for sustainability \\
Innovation & $\begin{array}{l}\text { Of its business and future competitive advantage. } \\
\text { OI3 The company encourages employees to take initiative and behave innovatively in } \\
\text { all of its different units/areas/departments. }\end{array}$ \\
\hline
\end{tabular}

Note. Key to Variables: MI - Marketing Innovation; PRDI1 - Product Innovation; PRCI -Process Innovation; OI2 Organizational Innovation.

With the objective of ensuring reliability and internal validity in qualitative research, Creswell, Plano Clark, Gutmann and Hanson (2003) suggest data triangulation, which requires the use of different sources of data information.

The qualitative phase of the study was conducted after the quantitative data analysis. This took the form of observation during day-to-day participation in the company and semi-structured interviews with the company's four directors. The objective was to attempt to determine whether perceptions of personnel at the tactical level (managers; coordinators; supervisors) were similar to perceptions of people at the strategic level (directors). Therefore, a qualitative phase of data collection was conducted, with semi-structured interviews and collection of secondary data (business documents, annual reports, and records related to knowledge and innovation management practices). The script for the semistructured interviews was developed based on the results of the literature review and results from analysis of the quantitative data. The interviewees were all four of the company's directors, as shown in Table 4. 
Table 4

Directors Interviewed in the Qualitative Phase of the Study

\begin{tabular}{llclcc}
\hline Identification & Position Held & $\begin{array}{c}\text { Time } \\
\text { Firm }\end{array}$ & Educational level & Age & $\begin{array}{c}\text { Duration of } \\
\text { Interview }\end{array}$ \\
\hline Interviewee 1 & $\begin{array}{l}\text { Managing Director, Finance and } \\
\text { Investor Relations }\end{array}$ & 18 years & postgraduate studies & 39 & $22 \mathrm{~min}$ \\
\hline Interviewee 2 & Chief Executive Officer & 16 years & postgraduate studies & 48 & 33 min \\
\hline Interviewee 3 & $\begin{array}{l}\text { Director, Paper and Packaging } \\
\text { Business }\end{array}$ & 9 years & postgraduate studies & 47 & 35 min \\
\hline Interviewee 4 & Director, Forestry Business & 2 years & postgraduate studies & 51 & 29 min \\
\hline
\end{tabular}

Note. Source: fieldwork findings.

The data collected were analyzed using descriptive analysis. After analysis of the qualitative data, secondary data provided by the firm collected from its websites and industry news websites (business documents, annual reports, records related to knowledge and innovation management practices), the information accumulated was triangulated and a comparative analysis was conducted of the two phases of the study.

This two-stage research method was deemed necessary in order to achieve a better understanding of the proposed framework, which is an attempt to answer the research questions through analysis of the relationships between the constructs involved.

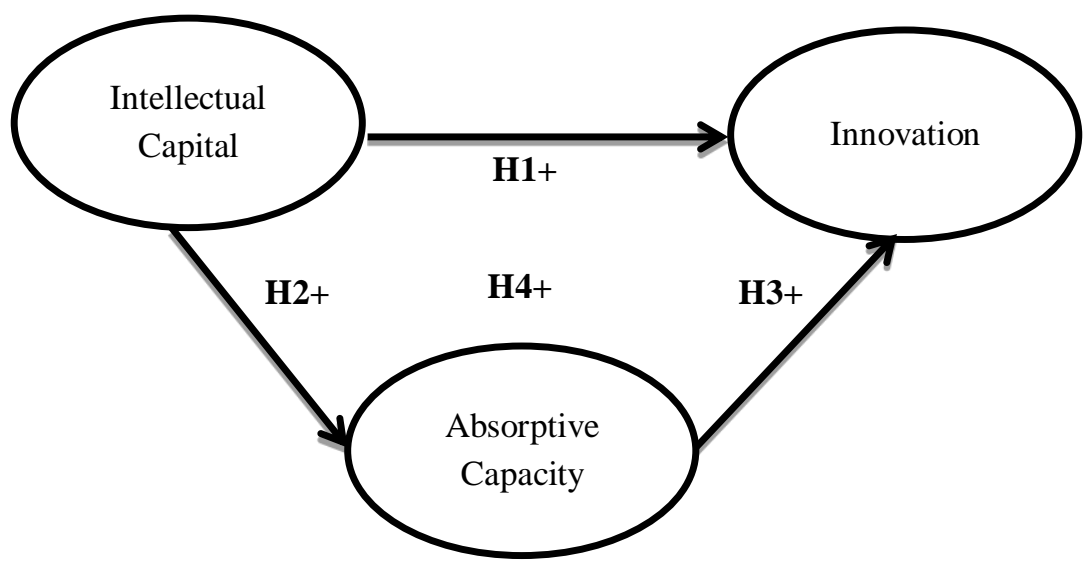

Figure 1. Theoretical-Empirical Framework

Working from the framework illustrated in Figure 1, the objective is to understand in an empirical setting whether intellectual capital can be developed through $\mathrm{AC}$ in order to potentiate innovation. It is inferred that if an organization is able to reutilize internal knowledge, absorb and assimilate external knowledge, it has the conditions to generate different types of innovation, especially if it uses new forms of management to do so. It is very likely that such a firm would be developing a dynamic capacity by means of AC.

Some studies indicate that AC plays a role mediating new knowledge creation (Van Den Bosch, Volberda, \& De Boer, 1999), while others have shown that knowledge acquisition has an indirect influence on innovation (Darroch \& McNaughton, 2003), or that AC and relationship networks are mediators of innovation capacity (Julien, Andriambeloson, \& Ramangalahy, 2004) and that AC is a mediator of the relationship between knowledge acquisition and innovation capacity (Liao, Fei \& Chen, 2007). By application of inductive reasoning, we propose that AC has a mediating effect on the relationship between intellectual capital and innovation. 


\section{Discussion of Results}

The paper and corrugated cardboard manufacturing industry is considered a traditional market and one in which the technology needed is relatively accessible and ever more globalized. As a result of these characteristics, globalization has allowed countries that had previously not been significant players in this market to become competitive suppliers, changing the industry's profile, which in turn means that the sector is characterized by intense competition for markets and for investment, but not by innovations or competitive advantages.

\section{Analysis of the quantitative data}

The quantitative data collection phase involved only managers, coordinators and supervisors (104 respondents from a total population of 149 management-level personnel). In other words, these are tactical-level employees who have a direct and constant relationship with the company's staff. The respondents were supervisors $(n=29,28 \%)$, coordinators $(n=58,56 \%)$ or managers $(n=17,16 \%)$.

The first data analysis performed was the Kolmogorov-Smirnov test of normality. The results showed that the data did not follow a normal distribution, with a p-value of 0.000 , further supporting the appropriateness of the choice to employ the PLS method (Hair et al., 2013).

\section{Evaluation of the measurement model}

The first stage was to use the measurement model estimation method, which measures both latent and manifest relationships between the variables observed. In this stage all of the first-order variables were replicated in the second-order constructs, as suggested by Hair et al. (2013) and Wetzels, Odekerken-Schröder and Van Oppen (2009). The first analysis structure constructed was examined for the factor loadings of all variables and then any variables with factor loadings between latent and manifest variables lower than 0.7 were eliminated, since these are considered unacceptable, according to Hair et al. (2013). This resulted in the final measurement model to be studied (Figure 2). It should be pointed out that variables were excluded, both from the first-order constructs and from the second-order constructs. 

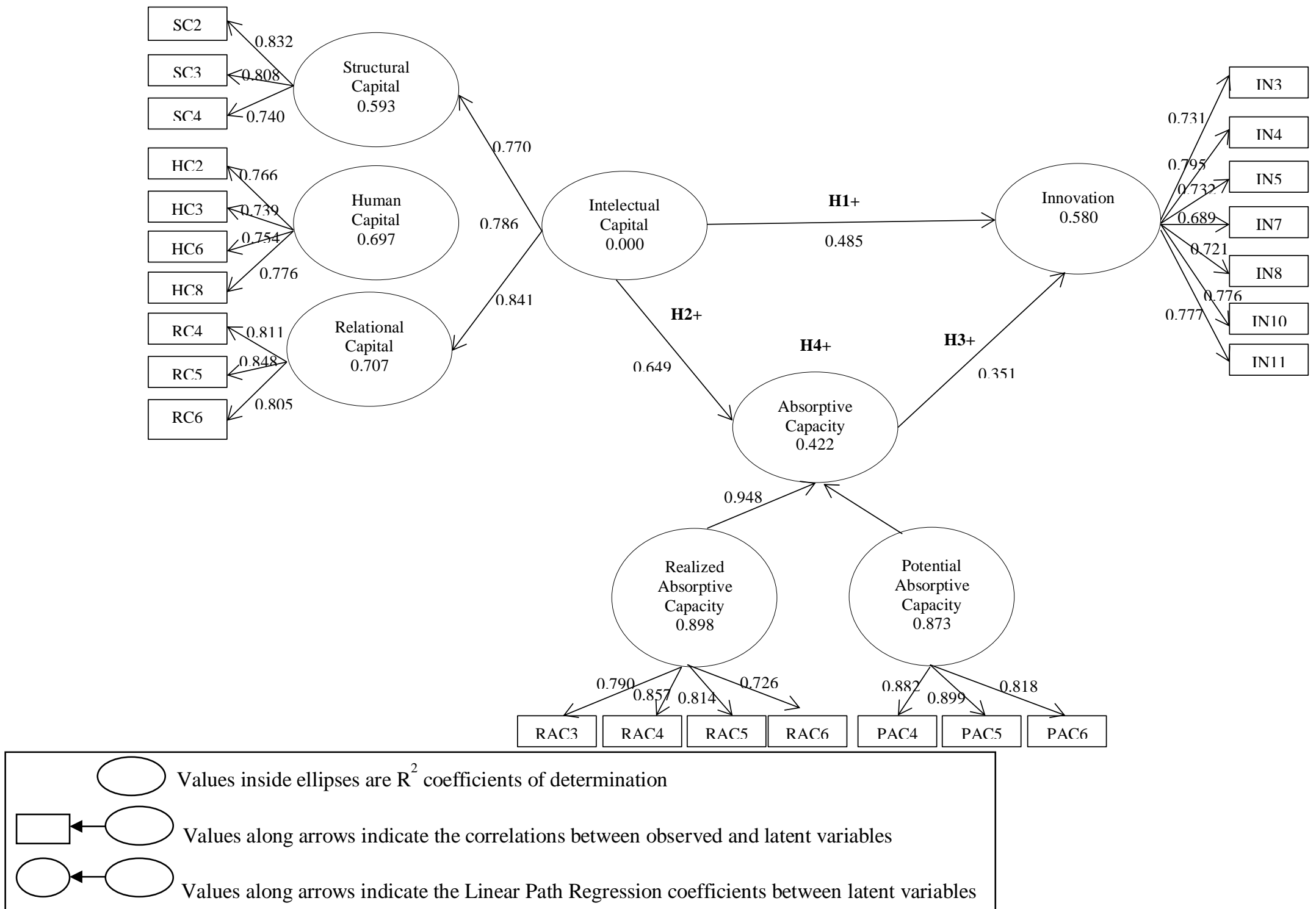

Figure 2. Structural Model (PLS)

The rectangles on the left represent questionnaire items, as follows: $\mathrm{SC}=$ structural capital, $\mathrm{HC}=$ human capital, $\mathrm{RC}=$ relational capital, $\mathrm{RAC}=$ realized $\mathrm{AC}, \mathrm{PAC}=$ potential $\mathrm{AC}$. 
The second stage conducted an analysis of discriminant validity, which indicates the extent to which the latent variables are independent of one another (Hair et al., 2013). The Fornell-Larcker criterion was used to compare the square roots of the average variance extracted (AVE) values for each construct with the correlations between constructs (Henseler, Ringle, \& Sinkovics, 2009). As shown in Table 5, it was found that all constructs' AVE values were higher than their correlations with other constructs, indicating discriminant validity between constructs.

Table 5

Pearson's Correlation Coefficients and Square Roots of AVEs for Latent Variables of First-order Constructs

\begin{tabular}{lcccccc}
\hline & $\begin{array}{c}\text { Potential } \\
\text { Absorptive } \\
\text { Capacity }\end{array}$ & $\begin{array}{c}\text { Realized } \\
\text { Absorptive } \\
\text { Capacity }\end{array}$ & $\begin{array}{c}\text { Structural } \\
\text { Capital }\end{array}$ & $\begin{array}{c}\text { Human } \\
\text { Capital }\end{array}$ & $\begin{array}{c}\text { Relational } \\
\text { Capital }\end{array}$ & Innovation \\
\hline Potential Absorptive Capacity & $\mathbf{0 . 8 6 6 9}$ & & & & & \\
\hline Realized Absorptive Capacity & 0.7726 & $\mathbf{0 . 7 9 7 9}$ & & & & \\
\hline Structural Capital & 0.4688 & 0.3582 & $\mathbf{0 . 7 9 4 2}$ & & & \\
\hline Human Capital & 0.5442 & 0.5372 & 0.3652 & $\mathbf{0 . 7 5 9 0}$ & & \\
\hline Relational Capital & 0.5021 & 0.4842 & 0.5529 & 0.4604 & $\mathbf{0 . 8 2 1 5}$ & \\
\hline Innovation & 0.6163 & 0.6364 & 0.5538 & 0.5775 & 0.5693 & $\mathbf{0 . 7 4 6 7}$ \\
\hline
\end{tabular}

Note. Values in bold (down the diagonal) are square roots of AVEs while all other figures are correlations between variables. Source: Study data.

The reliability and convergent validity of constructs were evaluated in terms of the internal consistency of constructs by calculating Cronbach's Alpha and Composite Reliability. It can be observed in Table 6 that all of the composite reliability scores are considerably higher than 0.6 , Cronbach's alphas are all higher than 0.7 and AVEs are all higher than 0.5; all of which can be considered satisfactory, according to recommendations in the literature (Nunnally \& Bernstein, 1994).

Table 6

Analysis of the Reliability of First and Second Order Constructs

\begin{tabular}{llcccc}
\hline SECOND-ORDER CONSTRUCTS & FIRST-ORDER CONSTRUCTS & Items & Alpha & CR & AVE \\
\hline Absorptive Capacity & Potential Absorptive Capacity & 3 & 0.834 & 0.901 & 0.752 \\
\cline { 2 - 6 } & Realized Absorptive Capacity & 4 & 0.808 & 0.875 & 0.637 \\
\hline Intellectual Capital & Structural Capital & 3 & 0.706 & 0.836 & 0.631 \\
\cline { 2 - 6 } & Human Capital & 4 & 0.756 & 0.845 & 0.576 \\
\cline { 2 - 6 } & Relational Capital & 3 & 0.759 & 0.862 & 0.675 \\
\hline & Innovation & 7 & 0.868 & 0.898 & 0.557 \\
\hline
\end{tabular}

Note. (a) The Items column indicates the number of variables comprising each construct on the final scales (after item purification); (b) Alpha: Cronbach's alpha; (c) CR: composite reliability; (d) AVE: average variance extracted. Source: Study data.

Convergent validity indicates the extent to which a scale is positively correlated with other measures of the same construct (Malhotra, 2012) and this characteristic also requires verification. In order to achieve high convergent validity, AVE values must be 0.50 or greater, since this means that the latent variable 
explains more than half of the variance of its indicators (Tabachnick \& Fidel, 2001). As shown in Table 6, all of the constructs achieved convergent validity, with AVE values greater than 0.50 .

\section{Analysis of the measurement model}

The structural model was tested using a two-step approach. First, coefficients of determination $\left(\mathrm{R}^{2}\right)$ were used to evaluate the quality of the adjusted model. Coefficients of determination provide a measure of the proportion of variation in the endogenous variables that is explained by the structural model and in this case are equal to the squares of the Pearson's correlation coefficients. In the social and behavioral sciences, J. Cohen (1988) suggests that $\mathrm{R}^{2}=2 \%$ can be classified as indicating a small effect, $\mathrm{R}^{2}=13 \%$ as indicating a medium effect, and $\mathrm{R}^{2}=26 \%$ as indicating a large effect. It will be observed from Table 7 that all $\mathrm{R}^{2}$ values are greater than $0.26 \%$, indicating a large effect, which is a good score for the model.

The second stage in analysis of the quantitative data was to test predictive relevance $\left(\mathrm{Q}^{2}\right.$, also known as the Stone-Geisser indicator), which assesses the adjusted model's precision and for which the criterion of evaluation is a value greater than zero (Hair et al., 2013). Additionally, the effect size ( $\mathrm{f}^{2}$, or Cohen indicator) was also calculated by addition and removal of constructs to and from the model (one by one). In this case, values from 0.02 to 0.15 are considered small, values from 0.15 to 0.35 are considered intermediate and values greater than 0.35 are considered large (J. Cohen, 1988).

It can be observed from Table 7 that predictive relevance $\left(\mathrm{Q}^{2}\right)$ scores were greater than zero and, in general, the effect size $\left(\mathrm{f}^{2}\right)$ was large, with just three constructs exhibiting intermediate effect.

Table 7

Predictive Relevance $\left(\mathbf{Q}^{2}\right)$ and Effect Size $\left(\mathbf{f}^{2}\right)$ of Constructs

\begin{tabular}{lll}
\hline & $\mathbf{Q}^{\mathbf{2}}$ & $\mathbf{F}^{\mathbf{2}}$ \\
\hline Potential Absorptive Capacity & 0.655847 & 0.484117 \\
\hline Realized Absorptive Capacity & 0.582682 & 0.395517 \\
\hline Absorptive capacity & $\mathbf{0 . 2 3 0 6 2 7}$ & $\mathbf{0 . 4 7 4 3 6 5}$ \\
\hline Structural Capital & 0.386742 & 0.275834 \\
\hline Human Capital & 0.361753 & 0.296317 \\
\hline Relational Capital & 0.492978 & 0.343846 \\
\hline Intellectual capital & $\mathbf{0 . 2 5 7 2 0 7}$ & $\mathbf{0 . 2 5 7 2 0 7}$ \\
\hline Innovation & $\mathbf{0 . 3 0 5 7 5 5}$ & $\mathbf{0 . 4 0 5 2 5}$ \\
\hline
\end{tabular}

Note. Source: analysis of fieldwork findings.

Therefore, based on analysis of quantitative data, the first three research hypotheses (H1, H2, H3) were confirmed. Path coefficients (Figure 2$)$ were significant $(\mathrm{p}<0.01)$ for all of the hypotheses, H1 $(\beta=0.649, \mathrm{t}=7.022), \mathrm{H} 2 \quad(\beta=0.351, \mathrm{t}=5.052), \mathrm{H} 3 \quad(\beta=0.485, \mathrm{t}=4.493)$. The effect sizes were also considered significant (Table 5). The $\mathrm{R}^{2}=0.58$ for innovation, which is moderate according to Hair $e t$ al. (2013), indicates an acceptable level of explanation of the endogenous variable.

Hypothesis 4 (H4) predicted that absorptive capacity would have a mediating effect. The SOBEL test (Sobel Test Calculator for the Significance of Mediation) was used to verify whether the mediator does mediate between the independent variable intellectual capital and the dependent variable innovation, as shown in Table 8. In management studies investigating single mediation effects, the Sobel test is used to compare the strength of the indirect effect that an independent variable exerts on the dependent variable, in which the null hypothesis is that this effect is equal to zero (Baron \& Kenny, 1986). 
Table 8

Test of Mediation

\begin{tabular}{cccc}
\hline Independent variable & Dependent variable & Sobel* $^{*}$ & Variance Accounted For \\
\hline Intellectual capital & Innovation & 3.64 & 0.3195 \\
\hline
\end{tabular}

Note. * Sobel statistics follow a z-test distribution, so values $>1.96$ indicate $\mathrm{p}<0.05$.

Since the relationship is significant when $\mathrm{p} \leq 0.05$, in this case we observe that the hypothesis is supported, which shows that absorptive capacity does play a mediating role. In order to confirm the moderating effect of AC, the Variance Accounted For (VAF, or Variance Explained) test proposed by Hair et al. (2013) was also conducted when we performed the calculation suggested by Hair et al. (2013) the resulting variance explained ( $\mathrm{VAF}=0.3195$ or $31 \%$ ) demonstrated partial mediation, as suggested by the author $(20 \% \leq \mathrm{VAF} \leq 80 \%)$. As such, the hypotheses proposed in this study have been supported, as shown in Table 9.

Table 9

\section{Results of Tests of Hypotheses}

\begin{tabular}{|c|c|c|}
\hline & Hypotheses & Status \\
\hline H1 & $\begin{array}{l}\text { The greater an organization's intellectual capital is, the greater will be its capacity to generate } \\
\text { innovation. }\end{array}$ & Supported \\
\hline H2 & The greater the organization's intellectual capital is, the greater will be its absorptive capacity & Supp \\
\hline H3 & $\begin{array}{l}\text { The greater an organization's absorptive capacity is, the greater will be its capacity to } \\
\text { generate innovation. }\end{array}$ & Sup \\
\hline H4 & Absorptive capacity mediates the relationship between intellectual capital and innovation & Supported \\
\hline
\end{tabular}

Note. Source: Data from research.

\section{Analysis of the qualitative data}

Based on the data collected during the quantitative phase and the results from the in loco research (observations in the field) a need was perceived to understand the perceptions of people at the strategic level of the organization (directors) with regard to the same variables about which tactical level management had been questioned during the quantitative phase. A second data collection phase consisting of semi-structured interviews was therefore conducted. All four company's directors took part in this stage as interviewees. They had been director level managers for an average of nine years. These interviewees had a strategic overview of both the company's past and future.

The results revealed that the company was engaging in a range of actions to develop its intellectual capital. The directors made it clear that the company engages actions to develop its employees' competencies and also training and education programs. The firm already had, and was further developed, processes for management of structural capital, but the mechanisms were still going through a process of development and maturation. The directors' perceptions of the relational capital dimension revealed a concern with management of the company's stakeholder relations. The firm's primary focus is on customer relations, but it also engages in actions focused on suppliers and the community.

\footnotetext{
"The underlying objective of our training program is the basic competencies and those that differentiate, which is part of the strategic plan; we have identified twelve competencies that will help the company to achieve its objectives for the future. These competencies guide the personal development plans (PDP) we have for personnel at all levels". (Interviewee 1) (verbal communication - human capital).
} 
"We've been making efforts on two fronts: 1 . We maintain a management of excellence log in which we write down all our management practices and assess their adequacy; 2. There is an ongoing process to review all of the departments' processes that is being carried out by the risk management team and has started with the initial objective of identifying the processes. So we've been making progress, whether in the risk management process or in continuous improvement with Kaizen weeks, we now have more extensive records than we used to have". (Interviewee 3) (verbal communication - structural capital).

"We try to help our customers to prosper, acting ethically, through certain actions that make us different in terms of customer focus. We have adopted an entire attitude of commitment to our customers' businesses and to transparency in our relations". (Interviewee 2) (verbal communication - relational capital).

It can therefore be observed from the directors' responses that the company does implement actions for the management of intellectual capital. However, it can also be perceived that, at times, their perceptions differ, to the extent that the directors are more critical in their analysis of the processes for management of human and structural capital. In contrast, the responses of tactical-level management personnel on the subject of relational capital were more conservative, which suggests that they have less comprehensive knowledge of the company's activities in this dimension. Table 10 lists some of the company's practices that were mentioned in the interviews.

Table 10

\section{Practices for Promotion of Intellectual Capital}

\begin{tabular}{ll}
\hline Dimension & Practices mentioned \\
\hline Human Capital & a) Stimulation of employees' creativity; \\
& b) Ongoing educational development; \\
& c) Improvement of competencies that the company judges to be important to its growth; \\
& d) Construction of an environment that encourages employees to innovate in their jobs. \\
\hline Structural Capital & a) Implementation of a suggestions program; \\
& b) Structural improvements based on new technologies; \\
\hline c) Utilization of mechanisms to control wastage. \\
\hline
\end{tabular}

Note. Source: Analysis of fieldwork findings.

The second stage of the interviews was designed to discover whether the company was engaged in activities to foster AC, whether potential or realized. The directors' responses with regard to potential $\mathrm{AC}$ revealed that their perceptions were more critical, outlining points in need of improvement, for example, related to the ability to employ existing knowledge. In their analyses of realized AC, the directors observed that the company still needed to progress further, since this capacity can enable application of knowledge acquired externally within the organization.

"This is one area in which we still need to make progress, there is still lots of room for us to adopt benchmarking and structured visits abroad, because if you visit other firms you improve your observation skills and start to see certain things that you don't do here but that you could bring in quickly. We've been doing this in a more structured way for a few years now". (Interviewee 3) (verbal communication - potential $\mathrm{AC})$.

"We've developed our ability to apply knowledge, our people have been changing the technology as well, there are new things coming in and being developed on top of the infrastructure we already have. I realize that it is a challenge for us to do this as a routine and what we are trying to develop is the capacity to be open to change". (Interviewee 1) (verbal communication - realized AC). 
Analysis of the management and directors' responses with regard to the construct AC and its dimensions revealed that the tactical level personnel felt that the company was engaged in all of the characteristics related to development of this capacity. In contrast, the strategic level directors were aware that the company still needs to concentrate hard on developing this capacity because it engages in few management practices oriented towards the development of AC. What can be observed from the directors' responses is that isolated actions are taken which have specific effects on the organization's management process, but this process is still going through a continuous process of improvement. Notwithstanding, certain of the company's management practices are related to development of AC, as summarized in Table 11.

Table 11

\section{Practices for Promotion of Absorptive Capacity}

\begin{tabular}{|c|c|}
\hline Dimension & Practices mentioned \\
\hline \multirow[t]{3}{*}{ Potential absorptive capacity } & a) Assimilation of new technologies; \\
\hline & b) Use of existing knowledge internally; \\
\hline & $\begin{array}{l}\text { c) Use of benchmarking to understand other firms' development and } \\
\text { technologies. }\end{array}$ \\
\hline \multirow[t]{4}{*}{ Realized absorptive capacity } & a) Adaptation of technologies to the firm's requirements; \\
\hline & b) Development of rapid responses to external or internal change; \\
\hline & c) Application of technical knowledge; \\
\hline & d) Development of the capacity to convert knowledge into patents. \\
\hline
\end{tabular}

Note. Source: Analysis of fieldwork findings.

The third stage of the interviews focused on analysis of the innovation process within the company. The objective was to understand how the directors perceived the innovation process. Their responses show that the company is still developing the four types of innovation (position, process, product and paradigm), some in a more rapid manner and others in more conservative ways, but always taking actions based on the company's strategic planning.

"We haven't innovated greatly in position (marketing) because our market is very traditional. There aren't many channels, the channel is direct sales. I suppose our innovation was to develop the direct-sales model. We are reducing the number of sales representatives because we believe deeply in the direct relationship with the customer with no intermediaries". (Interviewee 3) (verbal communication - position innovation).

"We innovate less in product, but in process innovation we are learning. It's not such a dynamic process, partly because of the sector and partly because of our maturity with relation to this". (Interviewee 2) (verbal communication - product innovation).

"We are always in search of technological improvements, and this has been the company's focus because of the need to increase productivity and efficiency, which can only be achieved with technological changes and investment". (Interviewee 1) (verbal communication - process innovation).

“Our company's management model is one of the most innovative that I know and I think it's a benchmark for the industry, the result of strategic planning. I don't know if I could claim we are pioneers in innovation, because the paper and packaging sector is a conservative industry, but it is true that we are above average and on the right path, we could be going a bit quicker, but we have the structure to improve". (Interviewee 4) (verbal communication - paradigm innovation).

The directors' responses show that the company structure is innovation-oriented and this is a recent process that has not yet borne much concrete fruit. However, with relation to the market and to its competitors, the company can be seen as a pioneer. As such, the interviews with the directors and analysis of the responses of management (managers, coordinators and supervisors) to the questionnaire 
show that the firm investigated engages in actions related to development of intellectual capital, AC and innovation. Practices can be identified in which efforts are focused on innovation, as shown in Table 12.

Table 12

\section{Practices for Promotion of Innovation}

\begin{tabular}{ll}
\hline Dimension & Practices mentioned \\
\hline Innovation & a) Supply of new products to market; \\
b) Improvement of existing products; \\
c) Application of employees' ideas to improve products; \\
d) Improvements to production methods; \\
e) Utilization of new technologies; \\
f) Construction of an innovation-oriented culture; \\
g) Development of entrepreneurial behavior.
\end{tabular}

Note. Source: Analysis of fieldwork findings.

It is clear from both the interviews with directors and the analysis of responses from management (managers, coordinators and supervisors) that the company investigated takes actions to develop intellectual capital, AC and innovation.

\section{General analysis}

There were positive relationships between intellectual capital, AC and innovation in both the qualitative and the quantitative stages of this study, which allows us to infer that, because the company has adopted mechanisms for participative management, implemented an employee incentive system and developed its relations with its stakeholders, it develops its own AC. As such, it is potentiating its capacity to externalize the knowledge acquired through innovations that produce results for the organization.

By means of analysis of both quantitative and qualitative data, this study has demonstrated the relationships between intellectual capital, $\mathrm{AC}$ and innovation using a proposed framework for the case under analysis. It was found that the company investigated has a management structure (that values ongoing development of its employees and of its relations with its stakeholders) in order to construct an environment that fosters innovation and to identify improvements that can be made to products, processes and sales.

We found out that this company has developed a structure for management of innovation that makes it a pioneer in the Brazilian paper and cellulose industry. We observed the creation of a new innovation management context capable of generating value, even in an industry in which innovation is not a factor of competitive differentiation.

We have presented practices for management of intellectual capital and development of AC, offering other companies in the sector the opportunity to encounter a new structure for management of internal and external resources that is capable of promoting the innovation capacity.

Considering that managers should construct management processes that are appropriate for acquisition of knowledge through organizational learning, they should also ensure that the environment is conducive to sharing of tacit knowledge between the people in the organization. Objectively speaking, an organization should construct its mechanisms for AC and in this paper we have presented certain avenues that can be of use in this process.

Finally, we must also value the mediating role of absorptive capacity in the relationship between intellectual capital and innovation. Placed in mediating between development processes of intellectual 
capital and generation of innovation, absorptive capacity (through associated practices and procedures) shows conditions to mobilize the appropriate knowledge in the form of intellectual capital.

\section{Conclusions}

The first challenge of this study was to compose a research framework for the case in study. The aim was to define the general characteristics of the absorptive capacity construct in that environment as well as learning its main dynamic relations, considering its role in generating innovation. This framework not only directed the main activities of research-collection and systematization of knowledge/information and analysis of results, but also enabled an assessment of the company concerning the absorptive capacity, through quantitative and qualitative research stages. Then, the four proposed hypotheses were confirmed, from which the most important in terms of contribution to the debate is what places the absorptive capacity as a mediator of the relationship between intellectual capital and innovation.

In this respect, the adequacy of the framework to the case study puts it as a theoretical and empirical contribution of this work and also as an alternative for future studies that address the characteristics and dynamics of the absorptive capacity construct in unique case studies, always respecting the specificity of each case and the necessary methodological adaptation to other contexts and situations. One cannot, however, disregard the limitation coming from the condition of the final adjusted model, with its factor loadings and construct validity, which makes it applicable only in the specific configuration of the investigated organization, since this was a single case study. In addition, highlighting the cross-sectional study is vulnerable to the influence of the organizational context, and therefore subject to change over time.

But surely their empirical results are what distinguished this work. The presence of practice traces, capable of mobilizing the absorptive capacity was observed, both the upstream in relation to the intellectual capital as the downstream in the innovation generation phase. This finding revealed that the framework dynamics is sustained by the mobilization of certain routines and working practices in the relationship between intellectual capital and CA, as well as between $\mathrm{CA}$ and the generation of innovation. They are practices associated with forms of knowledge from the intellectual capital, structural size of the company and the relationship with stakeholders, as highlighted in the analysis stage. But, if this discovery reveals the presence of a dynamics that can be associated with the notion of absorptive capacity, on the other hand, it is observed that this practical portfolio is not arranged in synergy with the CA. It is organized to meet other business objectives, but that in an analysis based on the perspective of the CA can also be included in the same perspective. Therefore, the case study does not express a consolidated example of absorptive capacity, but a training process under construction, for whose support, the company has adopted engagement policies of its personnel-participatory management and incentive systems and, externally, stimulated the relationships with its stakeholders.

In any case, this reflection on the greater or the lesser synergy of management practices in relation to the acquisition, internalization, processing or also the application of knowledge (Duchek, 2015), points out the future possibility of conceiving a scale composed by different levels of mobilization of absorptive capacity, in which different companies representing different states of CA would be classified.

Suggestions for future research include the application of the theoretical framework and conceptual model to a larger sample in order to find out whether other firms, belonging to traditional industries, have similar behaviors. Also, there is the suggestion to adapt and apply the research instrument in samples with more dynamic sectors, because, as a rule, dynamic environments require greater absorptive capacity of enterprises, considering that this is a necessary condition for the development of innovation and rapid responses. Still, in the field of theoretical and empirical contribution, we noted in the analysis phase that the impasses and advances of some processes and 
practices that mobilize the $\mathrm{AC}$ could be better understood if examined from the perspective of Experiential Learning, Action Learning and Organizational Routines.

\section{References}

Acedo, F. J., Barroso, C., \& Galan, J. L. (2006). The resource-based theory: dissemination and main trends. Strategic Management Journal, 27(7), 621-636. http://dx.doi.org/10.1002/smj.532

Baron, R. M., \& Kenny, D. A. (1986). The moderator-mediator variable distinction in social psychological research: conceptual, strategic, and statistical considerations. Journal of Personality and Social Psychology, 51(6), 1173-1182. http://dx.doi.org/10.1037/00223514.51.6.1173

Camisón, C., \& Forés, B. (2010). Knowledge absorptive capacity: new insights for its conceptualization and measurement. Journal of Business Research, 63(7), 707-715. http://dx.doi.org/10.1016/j.jbusres.2009.04.022

Chen, Y. S., Lin, M. J. J., \& Chang, C. H. (2009). The positive effects of relationship learning and absorptive capacity on innovation performance and competitive advantage in industrial markets. $\begin{array}{lll}\text { Industrial Marketing } & \text { Management, } & \text { 38(2), }\end{array}$ http://dx.doi.org/10.1016/j.indmarman.2008.12.003

Cohen, J. (1988). Statistical power analysis for the behavioral sciences (2nd ed.). New York: Psychology Press.

Cohen, W. M. (2010). Fifty years of empirical studies of innovative activity and performance. Handbook of the Economics of Innovation, 1, 129-213. http://dx.doi.org/10.1016/S0169-7218(10)01004-X

Cohen, W. M., \& Levinthal, D. A. (1989). Innovation and learning: the two faces of R \& D. The Economic Journal, 99(397), 569-596. http://dx.doi.org/10.2307/2233763

Cohen, W. M., \& Levinthal, D. A. (1990). Absorptive capacity: a new perspective on learning and innovation. Administrative Science Quarterly, 35(1), 128-152. http://dx.doi.org/10.2307/2393553

Costa, R. V., Fernández, C. F. J., \& Dorrego, P. F. (2014). Critical elements for product innovation at Portuguese innovative SMEs: an intellectual capital perspective. Knowledge Management Research \& Practice, 12(3), 322-338. http://dx.doi.org/10.1057/kmrp.2014.15

Creswell, J. W., Plano Clark, V. L., Gutmann, M. L., \& Hanson, W. E. (2003). Advanced mixed methods research designs. In A. Tashakkori \& C. Teddlie (Eds.), SAGE Handbook on mixed methods in the behavioral and social sciences (pp. 209-240). Thousands Oak, CA: Sage Publications.

Darroch, J., \& McNaughton, R. (2003). Beyond market orientation: knowledge management and the innovativeness of New Zealand firms. European Journal of Marketing, 37(3/4), 572-593. http://dx.doi.org/10.1108/03090560310459096

Davenport, T. H., \& Prusak, L. (1998). Working knowledge: how organizations manage what they know. New York: Harvard Business School Press.

Demartini, P., \& Paoloni, P. (2013). Implementing an intellectual capital framework in practice. Journal of Intellectual Capital, 14(1), 69-83. http://dx.doi.org/10.1108/14691931311289020

Duchek, S. (2013). Capturing absorptive capacity: a critical review and future prospects. Schmalenbach Business Review, 65, 312-329. 
Duchek, S. (2015). Designing absorptive capacity? An analysis of knowledge absorption practices in German high-tech firms. International Journal of Innovation Management, 19(4), 1550044. http://dx.doi.org/10.1142/S1363919615500449

Dumay, J., \& Garanina, T. (2013). Intellectual capital research: a critical examination of the third stage. Journal of Intellectual Capital, 14(1), 10-25. http://dx.doi.org/10.1108/14691931311288995

Edvinsson, L. (2013). IC 21: reflections from 21 years of IC practice and theory. Journal of Intellectual Capital, 14(1), 163-172. http://dx.doi.org/10.1108/14691931311289075

Edvinsson, L., \& Malone, M. S. (1998). Capital intelectual: descobrindo o valor real de sua empresa pela identificação de seus valores internos. São Paulo: Makron Books.

Eisenhardt, K. M., \& Santos, F. M. (2002). Knowledge-based view: a new theory of strategy. In A. Pettigrew, H. Thomas, \& R. Whittington (Eds.), Handbook of strategy and management (Chapter 7, pp. 139-164). http://dx.doi.org/10.4135/9781848608313.n7

Flatten, T. C., Engelen, A., Zahra, S. A., \& Brettel, M. (2011). A measure of absorptive capacity: scale development and validation. European Management Journal, 29(2), 98-116. http://dx.doi.org/10.1016/j.emj.2010.11.002

Freeman, C., \& Soete, L. (2008). A economia da inovação industrial. Campinas: Editora da Unicamp.

Gracioli, C., Godoy, L. P., Lorenzett, D. B., \& Godoy, T. P. (2012). Capital intelectual: uma ferramenta inovadora na busca por vantagens competitivas. Revista de Administração e inovação, 9(4), 96120. http://dx.doi.org/10.5773/rai.v9i4.778

Guthrie, J., Ricceri, F., \& Dumay, J. (2012). Reflections and projections: a decade of intellectual capital accounting research. The British Accounting Review, 44(2), 68-82. http://dx.doi.org/10.1016/j.bar.2012.03.004

Hagemeister, M., \& Rodríguez-Castellanos, A. (2010). Organisational capacity to absorb external R\&D: industrial differences in assessing intellectual capital drivers. Knowledge Management Research \& Practice, 8(2), 102-111. http://dx.doi.org/10.1057/kmrp.2010.5

Hair, J. F., Black, W. C., Babin, B. J., Anderson, R. E., \& Tatham, R. L. (2009). Análise multivariada de dados (6a ed.). Porto Alegre: Bookman.

Hair, J. F., Hult, G. T. M., Ringle, C., \& Sarstedt, M. (2013). A primer on partial least squares structural equation modeling (PLS-SEM). Los Angeles: SAGE Publications.

Hair, J. F., Ringle, C. M., \& Sarstedt, M. (2011). PLS-SEM: indeed a silver bullet. Journal of Marketing Theory and Practice, 19(2), 139-152. http://dx.doi.org/10.2753/MTP1069-6679190202

Henseler, J., Ringle, C., \& Sinkovics, R. (2009). The use of partial least squares path modeling in international marketing. In R. R. Sinkovics \& P. N. Ghauri (Eds.), New challenges to international marketing - Advances in international marketing (Vol. 20, pp. 277-319). Bingley: Emerald Group Publishing Limited.

Ienciu, N. M., \& Matis, D. (2011). A theoretical framework of intellectual capital. International Journal of Business Research, 11(2), 131-136.

Jeon, J., Hong, S., Ohm, J., \& Yang, T. (2015). Causal relationships among technology acquisition, absorptive capacity, and innovation performance: evidence from the pharmaceutical industry. PloS One, 10(7), e0131642. http://dx.doi.org/ 10.1371/journal.pone.0131642

Julien, P. A., Andriambeloson, E., \& Ramangalahy, C. (2004). Networks, weak signals and technological innovations among SMEs in the land-based transportation equipment sector. 
$\begin{array}{llll}\text { Entrepreneurship \& } \quad \text { Regional Development, } & \text { 16(4), }\end{array}$ http://dx.doi.org/10.1080/0898562042000263249

Lane, P. J., Koka, B. R., \& Pathak, S. (2006). The reification of absorptive capacity: a critical review and rejuvenation of the construct. Academy of Management Review, 31(4), 833-863. http://dx.doi.org/10.5465/AMR.2006.22527456

Leal-Rodríguez, A. L., Roldán, J. L., Ariza-Montes, J. A., \& Leal-Millán, A. (2014). From potential absorptive capacity to innovation outcomes in project teams: the conditional mediating role of the realized absorptive capacity in a relational learning context. International Journal of Project Management, 32(6), 894-907. http://dx.doi.org/10.1016/j.ijproman.2014.01.005

Liao, S. H., Fei, W. C., \& Chen, C. C. (2007). Knowledge sharing, absorptive capacity, and innovation capability: an empirical study of Taiwan's knowledge-intensive industries. Journal of Information Science, 33(3), 340-359. http://dx.doi.org/10.1177/0165551506070739

Lima, J. P. C., \& Antunes, M. T. P. (2011, junho). Reflexões teórico-metodológicas para a proposição de um plano teórico de categorização e classificação do capital intelectual. Anais do Congresso Associação Nacional dos Programas de Pós-graduação em Ciências Contábeis, Vitória, ES, Brasil, 5.

Lin, C., Wu, Y.-J., Chang, C., Wang, W., \& Lee, C.-Y. (2012). The alliance innovation performance of R\&D alliances - the absorptive capacity perspective. Technovation, 32(5), 282-292. http://dx.doi.org/10.1016/j.technovation.2012.01.004

Lin, T.-C., Chang, C. L., \& Tsai, W. C. (2016). The influences of knowledge loss and knowledge retention mechanisms on the absorptive capacity and performance of a MIS department. Management Decision, 54(7), 1757-1787. http://dx.doi.org/10.1108/MD-02-2016-0117

Luca, M. M. M. D., Maia, A. B. G. R., Cardoso, V. I. D. C., Vasconcelos, A. C. D., \& Cunha, J. V. A. D. (2014). Intangible assets and superior and sustained performance of innovative Brazilian firms. Brazilian Administration Review, 11(4), 407-440. Retrieved from http://www.scielo.br/pdf/bar/v11n4/1807-7692-bar-11-04-00407.pdf. http://dx.doi.org/10.1590/1807-7692bar2014130012

Machado, R. E., \& Fracasso, E. M. (2012, novembro). A influência dos fatores internos na capacidade absortiva e na inovação: proposta de um framework. Anais do Simpósio da Gestão da Inovação Tecnológica, Salvador, BA, Brasil, 27.

Malhotra, N. (2012). Pesquisa de marketing: uma orientação aplicada (6a ed.). Porto Alegre: Bookman.

Mariano, S., \& Walter, C. (2015). The construct of absorptive capacity in knowledge management and intellectual capital research: content and text analyses. Journal of Knowledge Management, 19(2), 372-400. http://dx.doi.org/10.1108/JKM-08-2014-0342

Murovec, N., \& Prodan, I. (2009). Absorptive capacity, its determinants, and influence on innovation output: cross-cultural validation of the structural model. Technovation, 29(12), 859-872. http://dx.doi.org/10.1016/j.technovation.2009.05.010

Nahapiet, J., \& Ghoshal, S. (1998). Social capital, intellectual capital, and the organizational advantage. Academy of Management Review, 23(2), 242-266. http://dx.doi.org/10.5465/AMR.1998.533225

Nunnally, J. C., \& Bernstein, I. H. (1994). Psychometric theory (3rd ed.). New York: MGraw-Hill.

Rogers, E. M. (1962). Diffusion of innovations. New York: Free Press. 
Santos, D. F. L., Basso, L. F. C., \& Kimura, H. (2012). A estrutura da capacidade de inovar das empresas brasileiras: uma proposta de construto. Revista de Administração e Inovação, 9(3), 103-128. http://dx.doi.org/10.5773/rai.v9i3.750

Schultz, T. W. (1961). Investment in human capital. The American Economic Review, 51(1), 1-17.

Schumpeter, J. A. (1997). Teoria do desenvolvimento econômico: uma investigação sobre lucros, capital, crédito, juro e o ciclo econômico. São Paulo: Nova Cultural. (Obra original publicada em 1934).

Stoeckicht, I. P., \& Soares, C. A. P. (2012). The importance of strategically managing intellectual capital to develop innovative capacity in Brazilian companies. International Journal of Engineering Research and Innovation, 4(1), 21-29. Retrieved from http://ijeri.org/IJERIArchives/issues/spring2012/papers/IJERI\%20spring\%202012\%20v4\%20n1\%20(paper\%203).pdf

Sveiby, K. E. (1997). The new organizational wealth: managing and measuring knowledge-based assets. San Francisco: Berrett-Koehler Publishers.

Tabachnick, B., \& Fidell, L. (2001). Using multivariate statistics (4th ed.). Boston: Allyn and Bacon.

Tidd, J., Bessant, J., \& Pavitt, K. (2008). Gestão da inovação (3a ed.). Porto Alegre: Bookman.

Tidd, J., Bessant, J., Pavitt, K., \& Wiley, J. (1998). Managing innovation: integrating technological, market and organizational change. London: John Wiley \& Sons Ltda.

Tortoriello, M. (2015). The social underpinnings of absorptive capacity: the moderating effects of structural holes on innovation generation based on external knowledge. Strategic Management Journal, 36(4), 586-597. http://dx.doi.org/10.1002/smj.2228

Tseng, C.-Y., Chang Pai, D., \& Hung, C.-H. (2011). Knowledge absorptive capacity and innovation performance in KIBS. Journal of Knowledge Management, 15(6), 971-983. http://dx.doi.org/10.1108/13673271111179316

Utterback, J. M. (1971). The process of technological innovation within the firm. Academy of Management Journal, 14(1), 75-88. http://dx.doi.org/10.2307/254712

Van Den Bosch, F. A. J., Volberda, H. W., \& De Boer, M. (1999). Coevolution of firm absorptive capacity and knowledge environment: organizational forms and combinative capabilities. Organization Science, 10(5), 551-568. http://dx.doi.org/10.1287/orsc.10.5.551

Vicente-Oliva, S., Martínez-Sánchez, A., \& Berges-Muro, L. (2015). Research and development project management best practices and absorptive capacity: Empirical evidence from Spanish firms. International Journal of Project Management, 33(8), 1704-1716. http://dx.doi.org/10.1016\%2Fj.ijproman.2015.09.001

Wang, C., \& Han, Y. (2011). Linking properties of knowledge with innovation performance: the moderate role of absorptive capacity. Journal of Knowledge Management, 15(5), 802-819. http://dx.doi.org/10.1108/13673271111174339

Wetzels, M., Odekerken-Schroder, G., \& Van Oppen, C. (2009). Using PLS path modeling for assessing hierarchical construct models: guidelines and empirical illustration. Management Information Systems Quarterly, 33(1), 177-195.

Zahra, S. A., \& George, G. (2002). Absorptive capacity: a review, reconceptualization, and extension. Academy of Management Review, 27(2), 185-203. http://dx.doi.org/10.5465/AMR.2002.6587995 
Zhang, M., Qi, Y., Wang, Z., Pawar, K., \& Zhao, X. (2015, January). The effects of intellectual capital and supplier knowledge integration on innovation. Academy of Management Proceedings, 11442. http://dx.doi.org/10.5465/AMBPP.2015.11442abstract

\section{Authors' Profiles}

Alessandra Cassol

Rua Victor Sopelsa, 3000, Bairro Salete, 89700-000, Concórdia, SC, Brazil. E-mail address: alessandracassol.adm@ gmail.com

Cláudio Reis Gonçalo

Rua João Coan, 400, Sala 408, Bloco 1, 88161-064, Biguaçu, SC, Brazil. E-mail address: claudioreisgoncalo@gmail.com

Roberto Lima Ruas

Av. Francisco Matarazzo, 612, Prédio C, Água Branca, 05001-100, São Paulo, SP, Brazil. E-mail address: roberuas@gmail.com 